\title{
BUPIS UNTUK MEWUJUDKAN GERAKAN LITERASI SEKOLAH MENYONGSONG GERNAS BAKU PADA GUGUS DAHLIA KECAMATAN PARAKAN KABUPATEN TEMANGGUNG TAHUN 2018
}

\author{
Siti Asiyah \\ UPT Dinas Pendidikan, Parakan \\ e-mail: sitiasiyah08@gmail.com
}

\begin{abstract}
Books are important world windows in human life. However, receiving a book that is only considered as something normal is not necessary if it is not read. Reading is very important for everyone. By reading, science will increase and be able to increase knowledge and insight. However, this reading activity has not been done much, especially for students. The benefits of reading for early childhood can add vocabulary, train children's memory, practice coordination, train child safety, develop children's interests, gather interest in reading children, recognize simple writing, recognize and understand letters, add child words, communicate quickly. The expected goal in the development of Bupis is to realize the School Literacy Movement to welcome Baku Gernas in Dahlia Cluster, Parakan District, Temanggung Regency. After Bupis development activities were carried out, the results of the teacher's skills showed the percentage of the suitability of the contents of the reading with the theme before the action was carried out by $65.7 \%$ can be increased to $80.7 \%$ after guidance was carried out. On other indicators, namely word selection of $69.4 \%$ increased to $77.8 \%$. While the results of observations of children's reading interest in the indicator of children taking time to read every day increased from $61.4 \%$ to $85.7 \%$, and indicators of pleasure when reading increased from $57.8 \%$ to $100 \%$. Based on the description in the discussion, it can be concluded that the development of Bupis can improve teacher skills and increase children's reading interest. The teacher who initially did not have the skills in making Bupis, with guidance that supports the teacher is able to improve skills in making Bupis in accordance with the theme of learning in PAUD institutions, the choice of words in making Bupis is also adjusted to the development budget by the child. The skills of teachers in developing Bupis with indicators averaged 79.25\%. Development of Bupis can also increase children's reading interest. Children who originally did not have the interest to read because of the absence of library facilities and other sources of information, with the existence of Bupis children's reading interest can be supported by an average indicator of $92.85 \%$.
\end{abstract}

Key words: Bupis, Literasi, Gernas Baku

Abstrak

Buku merupakan jendela dunia yang berperan penting dalam kehidupan manusia. Namun, seringkali buku hanya dianggap sebagai sesuatu hal biasa yang tak bernilai jika tidak dibaca. Membaca sangat penting bagi setiap orang. Dengan membaca, ilmu akan bertambah dan mampu meningkatkan pengetahuan dan wawasan. Namun kegiatan membaca ini belum banyak dilakukan, khususnya para peserta didik. Manfaat membaca bagi anak usia dini dapat menambah perbendaharaan kata, melatih daya ingat anak, melatih konsentrasi, melatih keberanian anak, mengembangkan imajinasi anak, merangsang minat baca anak, mengenal tulisan sederhana, mengenal dan memahami huruf, menambah kosa kata anak, komunikasi lancar. Tujuan yang diharapkan dalam pengembangan Bupis adalah untuk mewujudkan Gerakan Literasi Sekolah menyongsong Gernas Baku pada Gugus Dahlia Kecamatan Parakan Kabupaten Temanggung. Setelah dilakukan kegiatan pengembangan Bupis, hasil keterampilan guru menunjukkan persentase kesesuaian isi bacaan dengan tema sebelum diadakan tindakan sebesar $65,7 \%$ dapat ditingkatkan menjadi $80,7 \%$ setelah dilaksanakan pembimbingan. Pada indikator lain, yaitu pemilihan kata sebesar $69,4 \%$ meningkat menjadi $77,8 \%$. Sedangkan hasil observasi minat baca anak pada indikator anak meluangkan waktu untuk membaca setiap hari meningkat dari $61,4 \%$ menjadi $85,7 \%$, dan indikator merasa senang saat membaca meningkat 
dari $57,8 \%$ menjadi $100 \%$. Berdasarkan uraian pada pembahasan, dapat disimpulkan bahwa pengembangan Bupis dapat meningkatkan keterampilan guru dan meningkatkan minat baca anak. Guru yang semula belum mempunyai keterampilan dalam pembuatan Bupis, dengan pembimbingan yang berkelanjutan guru mampu meningkatkan keterampilannya dalam pembuatan Bupis yang sesuai dengan tema pembelajaran yang ada di lembaga PAUD, pemilihan kata-kata dalam pembuatan Bupis juga disesuaikan dengan tingkat perkembangan anak usia dini sehingga mudah dipahami oleh anak. Keterampilan guru dalam pengembangan Bupis dengan rata-rata indikator 79,25\%. Pengembangan Bupis juga dapat meningkatkan minat baca anak. Anak yang semula belum mempunyai minat baca karena ketiadaan sarana perpustakaan dan sumber informasi lain, dengan adanya Bupis minat baca anak dapat ditingkatkan dengan rata-rata indikator $92,85 \%$.

Kata Kunci: Bupis, Literasi, Gernas Baku

\section{PENDAHULUAN}

\section{Latar Belakang Masalah}

Pendidikan anak usia dini pada hakekatnya adalah pendidikan yang diselenggarakan dengan tujuan untuk menfasilitasi pertumbuhan dan perkembangan anak. Sebagaimana yang tercantum dalam UU No. 20 Tahun 2003 tentang Sistem Pendidikan Nasional, yang menyebutkan bawah pendidikan anak usia dini adalah suatu upaya pembinaan yang ditujukan kepada anak sejak lahir sampai dengan usia enam tahun yang dilakukan melalui pemberian rangsangan pendidikan untuk membantu pertumbuhan dan perkembangan jasmani dan rohani agar anak memiliki kesiapan dalam memasuki jenjang pendidikan lebih lanjut.

Pemerintah melalui Peraturan Menteri Pendidkan dan Kebudayaan Nomor 23 Tahun 2015 mengenai gerakan penumbuhan budi pekerti, mengembangkan Gerakan Literasi Sekolah. Salah satu kegiatan dalam gerakan tersebut adalah kegiatan 15 menit membaca buku non pelajaran sebelum pembelajaran dimulai. Kegiatan tersebut dilaksanakan untuk menumbuhkan minat baca dan meningkatkan keterampilan membaca peserta didik agar pengetahuan dapat dikuasai secara lebih baik. Dalam masyarakat modern, membaca dan menulis merupakan bagian yang tak terkesampingkan karena tanpa kemampuan ini dunia akan tertutup dan terbatas hanya pada apa yang ada di sekitar kita (Soenjono Dardjowidjojo, 2005 : 299). Materi baca berisi nilai-nilai budi pekerti, berupa kearifan lokal, nasional, dan global yang disampaikan sesuai tahap perkembangan peserta didik.
Manfaat membaca bagi anak usia dini dapat menambah perbendaharaan kata, melatih daya ingat anak, melatih konsentrasi, melatih keberanian anak, mengembangkan imajinasi anak, merangsang minat baca anak, mengenal tulisan sederhana, mengenal dan memahami huruf, menambah kosa kata anak, komunikasi lancar. Bahwa untuk mendukung program membaca 15 menit buku non pelajaran sebelum pembelajaran dimulai, dibutuhkan ketersediaan buku yang memenuhi kualitas, kelayakan, dan kesesuaian buku sesuai dengan jenjang usia pembacanya.

Hasil survey penilaian siswa pada PISA 2015 menunjukkan bahwa Indonesia berada di urutan ke 64 dari 72 negara. Menurut survey BPS 2015, 91,47\% anak usia sekolah lebih suka menonton televisi dan $13,11 \%$ yang suka membaca. Abad ke-21 membutuhkan anak-anak yang mampu berpikir kritis, kreatif, komunikatif dan mampu berkolaborasi yang menuntut orangtua untuk mendampingi anak-anaknya mampu menguasai kecakapan beragam literasi. Gerakan Nasional Orang Tua Membacakan Buku (Gernas Baku) adalah suatu gerakan untuk mendukung inisiatif dan peran keluarga Indonesia dalam meningkatkan minat baca anak melalui pembiasaan di rumah, di lembaga PAUD dan masyarakat. Tujuan gerakan ini adalah untuk membiasakan orang tua membacakan buku bersama anak, memperat hubungan sosial emosional antara anak dan orang tua, dan menumbuhkan minat baca sejak dini. Sedangkan kegiatan yang dilaksanakan di lembaga PAUD yaitu menyelenggarakan 
kelas orang tua, kelas inspirasi dengan tema menumbuhkan minat dan manfaat senang membaca.

Dengan adanya Gernas Baku, para orang tua lebih sering meluangkan waktunya untuk membacakan buku bagi anak dan memiliki peran di lembaga PAUD, sehingga ke depannya terbentuk perpustakaan di lembaga-lembaga PAUD yang dikelola oleh paguyuban orangtua.

Kendala yang dihadapi beberapa lembaga PAUD, termasuk di Gugus Dahlia Kecamatan Parakan dalam pelaksanaan gerakan literasi sekolah, khususnya untuk melaksanakan kegiatan membaca 15 menit sebelum pembelajaran dimulai adalah belum tersedianya perpustakaan dan bahan bacaan yang memadai. Dari 7 lembaga PAUD yang ada di Gugus Dahlia Kecamatan Parakan, baru 1 lembaga PAUD yaitu TKIT Mutiara Hati yang sudah mempunyai fasilitas perpustakaan, itupun belum dimanfaatkan secara maksimal karena keterbatasan bukubuku bacaan. Lembaga PAUD di Gugus Dahlia rata-rata hanya memiliki buku bacaan tidak lebih dari 20 buku.

Agar kegiatan membaca 15 menit sebelum kegiatan pembelajaran sebagai salah satu program dari GLS dapat terlaksana, diperlukan sebuah inovasi dalam penyediaan bahan bacaan yang sesuai dengan minat baca peserta didik dan tidak memerlukan biaya yang terlalu mahal. Inovasi yang dimaksud adalah dengan pembuatan Buku Tipis (Bupis) oleh pendidik di masing-masing lembaga PAUD di Gugus Dahlia Kecamatan Parakan. Bupis dapat dibuat sesuai dengan minat baca anak, dapat disesuaikan dengan tingkat perkembangan anak, dapat disesuaikan dengan kebutuhan dan lingkungan sekitar, biaya pembuatan yang sangat murah, sehingga dapat menjadi salah satu solusi bagi lembaga-lembaga PAUD di Gugus Dahlia untuk meningkatkan minat dan kemampuan mengenal keaksaraan awal bagi peserta didik.

\section{Permasalahan}

Berdasarkan latar belakang masalah di atas, maka dapat dirumuskan masalah "Apakah Bupis dapat mewujudkan Gerakan Literasi Sekolah menyongsong Gernas Baku pada Gugus Dahlia Kecamatan Parakan?”

\section{Tujuan}

Tujuan pengembangan Bupis adalah untuk mewujudkan Gerakan Literasi Sekolah menyongsong Gernas Baku pada Gugus Dahlia Kecamatan Parakan.

\section{Strategi Pemecahan Masalah}

Berdasarkan permasalah yang telah diuraikan di atas, maka penulis menetapkan strategi pemecahan masalah dengan memberikan tugas mandiri kepada guru-guru di lembaga PAUD Gugus Dahlia Kecamatan Parakan untuk mengembangkan Bupis. Pembuatan Bupis dapat disesuaikan dengan tingkat perkembangan dan minat anak usia dini, disesuaikan dengan kebutuhan lembaga.

\section{Manfaat Pengembangan Bupis}

1. Meningkatkan keterampilan pendidik dalam pembuatan bahan bacaan bagi peserta didik.

2. Meningkatkan minat baca peserta didik khususnya pengenalan keaksaraan awal.

3. Meningkatkan kualitas lembaga secara umum.

4. Menambah koleksi buku bacaan di lembaga.

\section{PEMBAHASAN \\ Prosedur Kegiatan}

Buku bacaan untuk anak-anak harus memiliki nilai-nilai yang bersifat personal dan nilai-nilai yang bersifat pendidikan. Mengandung nilai personal berarti bacaan yang dipilih berisi hal-hal yang memberikan kenikmatan, memperkuat cara berpikir, mengembangkan imajinasi, memberikan pengalaman, mengembangkan kemampuan berperilaku. Mengandung nilai pendidikan, berarti bacaan mengandung hal-hal yang dapat mengembangkan bahasa, membantu belajar bahasa, sekaligus membantu belajar menulis.

Penulis mengembangkan Bupis dengan rancangan bahwa Bupis adalah bahan bacaan yang didesain sedemikian rupa agar isi, tampilan dapat menarik perhatian peserta didik dengan menambahkan gambar yang mendukung isi bacaan, desain sampul yang menarik, memberikan warna-warna yang menarik di setiap tampilan Bupis. 
Bupis ini dikembangkan dengan memberikan tugas mandiri kepada pendidik di Gugus Dahlia Kecamatan Parakan Kabupaten Temanggung. Alasan penggunaan pendekatan tersebut adalah karena untuk mengembangkan media pembelajaran yang efektif dan mudah penerapannya sesuai dengan kondisi dan kebutuhan nyata di sekolah, selain itu untuk meningkatkan keterampilan pendidik dalam pembuatan Bupis.

Langkah-langkah pengembangan media pembelajaran Bupis :

1. Melakukan persiapan untuk merumuskan kerangka kerja.

2. Merumuskan kecakapan dan keahlian yang berkaitan dengan permasalahan yang akan dibahas dan menentukan tujuan.

3. Mengembangkan bentuk permulaan dari produk yang akan dihasilkan, meliputi persiapan komponen pendukung yang dibutuhkan, menyiapkan pedoman dan buku petunjuk, serta melakukan evaluasi terhadap kelayakan alat-alat pendukung.

4. Melakukan ujicoba dalam skala terbatas dengan melibatkan beberapa lembaga PAUD Gugus Dahlia Kecamatan Parakan. Pengumpulan dan analisis data dapat dilakukan dengan observasi dan wawancara.

5. Perbaikan pada produk awal yang telah dihasilkan berdasarkan hasil ujicoba awal. Perbaikan ini sangat mungkin dilakukan berulang kali, sesuai dengan hasil yang ditunjukkan dalam ujicoba terbatas, hingga diperoleh model utama yang siap diujicoba dalam skala luas.

6. Ujicoba utama yang melibatkan semua lembaga PAUD Gugus Dahlia Kecamatan Parakan.

7. Melakukan perbaikan dan penyempurnaan terhadap hasil uji coba skala luas, sehingga produk yang dikembangkan sudah berupa desain model operasional yang siap divalidasi.

8. Uji validasi model operasional yang telah dihasilkan.

9. Melakukan perbaikan akhir terhadap model yang dikembangkan.

10. Menyebarluaskan model / produk yang dikembangkan.

Bupis merupakan media yang digunakan untuk meningkatkan keterampilan pendidik dan meningkatkan kemampuan mengenal keaksaraan awal pada peserta didik di Gugus Dahlia Kecamatan Parakan Kabupaten Temanggung yang berbentuk buku mini dengan tebal maksimal 25 halaman. Buku berisi cerita atau gambar-gambar yang dikutip dari buku, majalah, koran atau sumber lain yang disesuaikan dengan tingkat perkembangan anak usia dini.

1. Bentuk dan Ukuran

Bupis berbentuk buku yang berukuran maksimal 21 x $15 \mathrm{~cm}$. Bentuk bupis tidak selalu persegi panjang atau persegi seperti pada umumnya, tetapi dapat dibentuk sedemikian rupa sehingga menarik bagi peserta didik, bentuk dapat disesuaikan dengan tema pembelajaran, misalnya bentuk mobil, ikan, rumah, dan lain sebagainya. Sampul Bupis dibuat berwarna dengan gambar yang menarik dan mendukung isi bacaan. Teks bacaan disajikan dengan gaya bahasa yang mudah dimengerti anak, tanpa mengurangi fungsi dalam memperkuat cara berpikir, mengembangkan imajinasi, memberikan pengalaman, mengembangkan kemampuan berperilaku, dan menyajikan pengalaman yang menyeluruh.

2. Alat, Bahan, dan Pembiayan

Bupis yang berbentuk buku dibuat dari kertas HVS ukuran kuarto untuk bagian dalam dan kertas buffalo atau karton bekas sebagai sampul. Gambargambar yang tertera dalam Bupis dapat diambil dari kalender, koran, dan majalah. Secara rinci, biaya untuk pembuatan Bupis dengan tebal 25 halaman adalah sebagai berikut :

Tabel 1. Bahan dan Biaya Pembuatan Bupis

\begin{tabular}{|c|c|c|c|c|}
\hline No & Uraian & Kuantitas & Satuan & Harga \\
\hline 1 & $\begin{array}{l}\text { Kertas } \\
\text { HVS }\end{array}$ & 13 & lembar & 900 \\
\hline 2 & $\begin{array}{l}\text { Kertas } \\
\text { buffalo }\end{array}$ & 1 & lembar & 500 \\
\hline 3 & $\begin{array}{l}\text { Cetak } \\
\text { hitam } \\
\text { putih }\end{array}$ & 13 & lembar & 3.900 \\
\hline 4 & $\begin{array}{l}\text { Cetak } \\
\text { sampul }\end{array}$ & 1 & lembar & 1.000 \\
\hline & $\begin{array}{l}\text { Total } \\
\text { biaya }\end{array}$ & & & 6.300 \\
\hline
\end{tabular}


3. Aplikasi Praktis dalam Kegiatan Belajar Mengajar

Bupis baru dimanfaatkan di TK IT Mutiara Hati sedangkan lembaga PAUD lain di Gugus Dahlia belum melaksanakan pembuatan Bupis. Setelah pengembangan Bupis mencapai tahap akhir, media tersebut diaplikasikan dalam proses pembelajaran yaitu pembelajaran literasi melalui kegiatan membaca 15 menit sebelum kegiatan pembelajaran dalam rangkaian gerakan literasi sekolah (GLS) di lembaga PAUD. Bupis ditempatkan di Sudut Baca Kelas, yaitu sudut di ruangan kelas yang digunakan untuk memajang koleksi bacaan dan karya anak (Depdiknas, 2016 : 17). Strategi pembalajaran yang dilaksanakan merujuk pada pedoman GLS dari Kemdikbud (Kemdikbud, 2016 : 6) khususnya pada langkah pembiasaan yang dilakukan melalui kegiatan membaca 15 menit sebelum pelajaran dimulai, yaitu :

\section{a. Membacakan Nyaring}

Dalam kegiatan ini, guru membacakan buku dengan suara nyaring. Membaca nyaring bertujuan untuk memotivasi anak agar mau membaca, membuat anak agar dapat membaca dan gemar membaca, memberikan pengalaman membaca yang menyenangkan, membangun komunikasi yang baik antara guru dan anak.

\section{b. Membaca dalam hatian}

Kegiatan ini dilaksanakan untuk menumbuhkan kebiasaan membaca pada anak. Anak diberi kesempatan membaca tanpa gangguan, untuk itu guru perlu menciptakan suasana yang tenang dan nyaman agar anak dapat berkonsentrasi. Guru membebaskan anak untuk memilih buku sesuai dengan minat dan kesenangannya. Dalam kegiatan ini, guru perlu memberikan motivasi agar anak membaca sampai selesai. Guru perlu menyediakan buku-buku dengan jenis dan judul yang bervariatif untuk menambah wawasan anak, tentunya isi bacaan sesuai dengan tingkat perkembangan anak.

Setelah kegiatan membaca 15 menit sebelum pembelajaran dimulai, guru dapat bertanya kepada anak tentang buku yang dibaca anak, hal-hal menarik apa yang ada dalam bacaan tersebut.

\section{Hasil Kegiatan}

1. Hasil Observasi Keterampilan Guru

Tabel 2. Keterampilan Guru

\begin{tabular}{|l|c|c|c|c|c|c|c|c|}
\hline \multirow{2}{*}{ Indikator } & \multicolumn{7}{|c|}{ Persentase } & Rata- \\
\cline { 2 - 8 } & L1 & L2 & L3 & L4 & L5 & L6 & L7 & \\
\hline $\begin{array}{l}\text { Kesesuai } \\
\text { an isi } \\
\text { dengan } \\
\text { tema }\end{array}$ & 95 & 85 & 75 & 80 & 80 & 75 & 75 & 80,7 \\
\hline $\begin{array}{l}\text { Pemiliha } \\
\text { n kata }\end{array}$ & 90 & 80 & 70 & 75 & 80 & 75 & 75 & 77,8 \\
\hline
\end{tabular}

2. Hasil Observasi Minat Baca Anak Tabel 3. Minat Baca Anak

\begin{tabular}{|l|c|c|c|c|c|c|c|c|}
\hline \multirow{2}{*}{ Indikator } & \multicolumn{7}{|c|}{ Persentase } & $\begin{array}{c}\text { Rat } \\
\text { a- } \\
\text { rata }\end{array}$ \\
\cline { 2 - 9 } & L & L & L & L & L & L & L & \\
& 1 & 2 & 3 & 4 & 5 & 6 & 7 & \\
\hline $\begin{array}{l}\text { Meluangkan } \\
\text { waktu untuk } \\
\text { membaca } \\
\text { setiap hari }\end{array}$ & 95 & 90 & 85 & 80 & 85 & 8 & 80 & 85,7 \\
\hline $\begin{array}{l}\text { Merasa } \\
\text { senang saat } \\
\text { membaca }\end{array}$ & 10 & 10 & 10 & 10 & 10 & 1 & 10 & 100 \\
\hline
\end{tabular}

Dari tabel diatas dapat diketahui bahwa keterampilan guru dalam pengembangan Bupis sudah baik, kesesuain isi bacaan dengan tema sudah baik, pemilihan kata-kata sesuai dengan tahap perkembangan anak usia dini sehingga mudah dipahami oleh anak. Dalam pembuatan Bupis, guru menampilkan gambar-gambar yang menarik sesuai dengan tema.

Dengan pengembangan Bupis di lembaga PAUD khususnya di Gugus Dahlia Kecamatan Parakan, berdasarkan tabel di atas minat baca anak sangat baik ditandai dengan indikator anak mau meluangkan waktu untuk meminjam buku, membuka-buka buku, dan membaca permulaan dengan mengenal keaksaraan awal dan anak merasa senang dengan adanya Bupis.

Data mengenai keterampilan guru menunjukkan bahwa keterampilan guru dalam pengembangan Bupis berada pada kriteria sangat tinggi. Guru dapat membuat Bupis yang disesuaikan dengan tahap perkembangan anak usia dini. Buku dibuat sedemikian rupa sehingga dapat menarik perhatian anak. Isi 
buku telah disesuaikan dengan tema pembelajaran sesuai dengan Kurikulum PAUD.

Meskipun belum semua lembaga PAUD yang ada di Gugus Dahlia Kecamatan Parakan dapat melaksanakan pengembangan Bupis di lembaga masing-masing, namun sejauh ini data menunjukkan telah adanya peningkatan yang cukup signifikan dalam keterampilan guru dalam pengembangan Bupis.

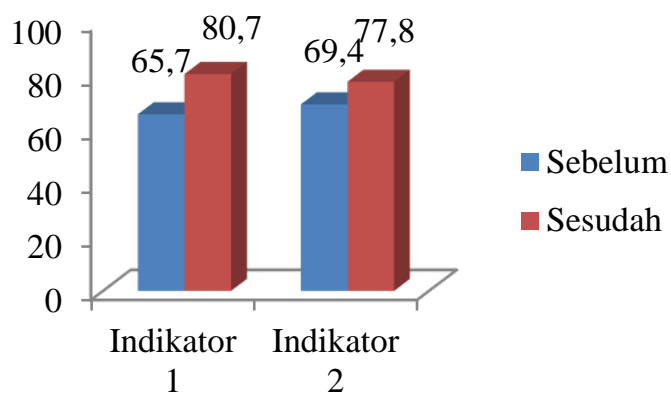

Gambar 1. Perbandingan Keterampilan Guru

Hasil keterampilan guru menunjukkan persentase kesesuaian isi bacaan dengan tema sebelum diadakan tindakan sebesar $65,7 \%$ dapat ditingkatkan menjadi $80,7 \%$ setelah dilaksanakan pembimbingan. Pada indikator lain, yaitu pemilihan kata sebesar $69,4 \%$ meningkat menjadi $77,8 \%$.

Data mengenai minat baca anak menunjukkan bahwa sebagian besar anak telah berada pada kriteria sangat tinggi. Data tersebut selaras dengan pendapat Adi W Gunawan (2005 : 8) yang mengemukakan cara menumbuhkan minat baca anak adalah dengan memberikan contoh, membacakan cerita pada anak, membiasakan anak membaca buku cerita yang disukainya.

Untuk itu peran guru maupun orang tua sangat penting dalam menumbuhkan minat baca anak. Guru perlu memberikan motivasi kepada anak, mengatur dan mengelola kegiatan membaca anak dengan mendinamiskan seluruh sumber bacaan yang ada, mengawasi proses membaca anak.

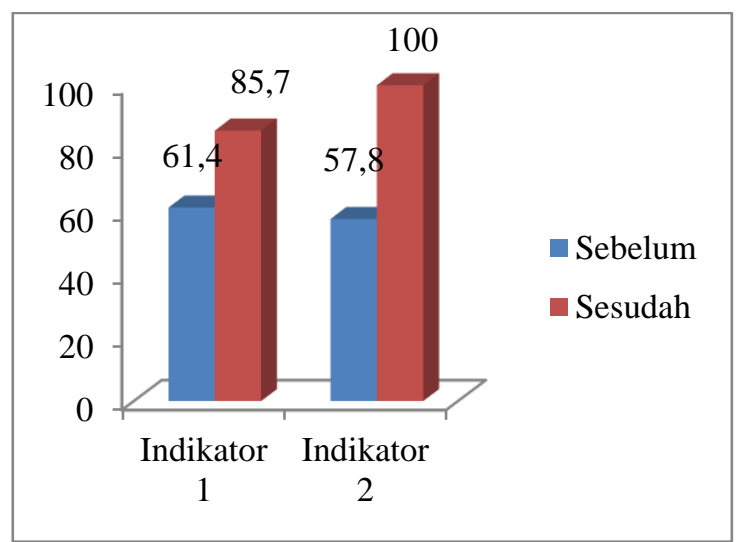

Gambar 2. Minat Baca Anak

Dari grafik di atas dapat dilihat bahwa pada indikator anak meluangkan waktu untuk membaca setiap hari meningkat dari $61,4 \%$ menjadi $85,7 \%$, dan indikator merasa senang saat membaca meningkat dari 57,8\% menjadi $100 \%$. Hal ini terjadi karena Bupis yang ada di lembaga dibuat sedemikian rupa sehingga dapat menarik perhatian anak untuk membacanya. Pernyataan tersebut selaras dengan pendapat Adi W Gunawan (2005 : 8), bahwa untuk menumbuhkan minat baca anak adalah (1) memberikan contoh, membacakan cerita kepada anak (3) membiasakan anak membaca buku cerita yang disukai secara konsisten. Dalam situasi di mana minat baca perlu ditumbuhkan, pendidik berperan penting untuk memotivasi dan menciptakan situasi pembelajaran yang kondusif.

\section{Dampak Kegiatan}

Dari serangkaian kegiatan pengembangan Bupis yang telah dilaksanakan di Gugus Dahlia Kecamatan Parakan berdampak positif terhadap keterampilan guru dalam pembuatan Bupis yang beragam sesuai dengan tingkat perkembangan anak usia dini, pemilihan kata, gambar dan tulisan yang tertera dalam Bupis dibuat sedemikian rupa sehingga mudah dipahami anak.

Selain itu, Bupis juga dapat meningkatkan minat baca anak usia dini di lembaga PAUD Gugus Dahlia Kecamatan Parakan. Dengan tersedianya bahan bacaan yang bervariatif akan menarik perhatian anak, sehingga minat baca anak pun meningkat. 


\section{Faktor Pendukung}

Faktor pendukung dalam pelaksanaan pembinaan di Gugus Dahlia Kecamatan Parakan sehingga dapat berjalan dengan baik adalah profesionalitas dan peran aktif guruguru binaan, adanya sarana dan prasarana yang cukup memadai sehingga dapat mendukung kegiatan pengembangan Bupis. Selain itu peran serta masyarakat khususnya orangtua murid yang berperan aktif dalam kegiatan pengembangan Bupis untuk mewujudkan Gernas Baku.

\section{Kendala}

Ada beberapa kendala yang dihadapi dalam aplikasi Bupis di lembaga PAUD Gugus Dahlia Parakan, yaitu :

1. Bupis dibuat dengan cara sederhana, menggunakan kertas HVS sehingga seiring waktu dan intensitas pembuatan sebagian Bupis rusak.

2. Ada beberapa guru yang masih memerlukan bimbingan dalam pengembangan Bupis karena guru yang bersangkutan kurang kreatif.

3. Sebagian guru masih menunggu adanya pelatihan yang khusus membahas tentang pengembangan pojok baca.

\section{Alternatif Pengembangan}

Dalam pengembangan kegiatan pembuatan Bupis di Gugus Dahlia Kecamatan Temanggung, ada beberapa alternatif pengembangan yang akan dilakukan salah satunya yaitu melibatkan orangtua murid dan masyarakat sekitar untuk turut berperan aktif dalam kegiatan pengembangan pembuatan Bupis di lembaga-lembaga PAUD sekitarnya untuk mewujudkan Gerakan Nasional Orang Tua Membacakan Buku. Sehingga tujuan Gernas Baku yang diharapkan akan tercapai yaitu menumbuhkan orang tua membacakan buku bersama anak, mempererat hubungan sosial emosional antara anak dan orang tua, serta menumbuhkan minat baca anak sejak dini.

Dengan adanya Gernas Baku, para orang tua lebih sering meluangkan waktunya untuk membacakan buku bagi anak dan memiliki peran di lembaga PAUD, sehingga kedepannya akan terbentuk perpustakaan di lembaga PAUD yang dikelola oleh paguyuban orang tua.

\section{KESIMPULAN}

Berdasarkan uraian pada pembahasan, penulis menyimpulkan bahwa pengembangan Bupis dapat meningkatkan keterampilan guru dan meningkatkan minat baca anak. Guru yang semula belum mempunyai keterampilan dalam pembuatan Bupis, dengan pembimbingan yang berkelanjutan guru mampu meningkatkan keterampilannya dalam pembuatan Bupis yang sesuai dengan tema pembelajaran yang ada di lembaga PAUD, pemilihan kata-kata dalam pembuatan Bupis juga disesuaikan dengan tingkat perkembangan anak usia dini sehingga mudah dipahami oleh anak. Keterampilan guru dalam pengembangan Bupis dengan rata-rata indikator $79,25 \%$.

Pengembangan Bupis juga dapat meningkatkan minat baca anak. Anak yang semula belum mempunyai minat baca karena ketiadaan sarana perpustakaan dan sumber informasi lain, dengan adanya Bupis minat baca anak dapat ditingkatkan dengan rata-rata indikator $92,85 \%$.

Dengan adanya pengembangan Bupis di lembaga PAUD Gugus Dahlia Kecamatan Parakan dapat mewujudkan Gerakan Literasi Sekolah (GLS) untuk menyongsong Gerakan Nasional Orang Tua Membacakan Buku (Gernas Baku) untuk mendukung inisiatif dan peran keluarga Indonesia dalam meningkatkan minat baca anak melalui pembiasaan di rumah, di lembaga PAUD dan masyarakat. Dengan membiasakan orang tua membacakan buku bersama anak, akan memperat hubungan sosial emosional antara anak dan orang tua, dan menumbuhkan minat baca sejak dini. Gerakan Nasional Orang Tua Membacakan Buku (Gernas Baku) serentak akan dilaksanakan tanggal 5 Mei 2018.

\section{Rekomendasi}

Pengembangan Bupis ini sangat sederhana dan biaya terjangkau. Diharapkan pengembangan Bupis di Gugus Dahlia dapat terus berjalan sehingga keterampilan guru dalam pembuatan Bupis semakin meningkat, dengan ketersediaan Bupis di lembaga PAUD akan merangsang dan menarik perhatian anak 
sehingga minat baca anak akan meningkat. Dalam pengembangan Bupis ini, penulis berharap dapat menjangkau sasaran yang lebih luas lagi yaitu semua lembaga PAUD yang ada di Kecamatan Parakan Kabupaten Temanggung.
Untuk menyongsong Gernas Baku yang akan dilaksanakan serentak pada tanggal 5 Mei 2018, diharapkan Ketua Gugus PAUD di Kecamatan Parakan untuk berperan aktif dalam pengembangan Bupis dalam rangka mewujudkan Gerakan Literasi Sekolah (GLS).

\section{DAFTAR PUSTAKA}

Abdurrahman, Mulyono. 1996. Pendidikan Bagi Anak Berkesulitan Belajar. Jakarta : Departemen Pendidikan dan Kebudayaan.

Dardjowidjojo, Soenjono. 2005. Psikolinguistik : Pengantar Pemahaman Bahasa Manusia. Jakarta : Yayasan Obor Indonesia.

Departemen Pendidikan dan Kebudayaan. 2016. Gerakan Literasi Sekolah di Sekolah Dasar. Jakarta : Depdikbud.

Kementerian Pendidikan dan Kebudayaan. 2018. Panduan Pelaksanaan Gerakan Nasional Orang Tua Membacakan Buku.

Gunawan AW. 2005. Apakah IQ Anak dapat Ditingkatkan dan Masalah-masalah Seputar

Pendidikan Anak yang Sering Dihadapi Orangtua dan Guru. Jakarta: Gramedia Pustaka Utama.

Schmoker, Mike. 2012. Menjadi Guru yang Efektif. Terjemahan. Jakarta : Erlangga.

Soedarsono. 2005. Speed Reading Sistem Membaca Cepat dan Efektif. Jakarta : PT. Gramedia Pustaka Utama.

Suryabrata, Sumadi. 2001. Psikologi Pendidikan. Jakarta : CV. Rajawali.

Tarigan, D. 2005. Materi Pokok Pendidikan Bahasa dan Sastra Indonesia di Kelas Rendah. Jakarta : Universitas Terbuka.

Udin S. Winataputra. 2003. Strategi Belajar Mengahar. Jakarta : Pusat Penerbitan Universitas Terbuka. 